\title{
Recycling of the Electronic Waste Applying the Plasma Reactor Technology
}

\author{
Marián Lázár, Natália Jasminská, Mária Čarnogurská, Romana Dobáková \\ Technical University of Košice \\ Faculty of Mechanical Engineering, Department of Power Engineering \\ e-mail:marian.lazar@tuke.sk, natalia.jasminska@tuke.sk,maria.carnogurska@tuke.sk, \\ romana.dobakova@tuke.sk
}

\begin{abstract}
The following paper discusses a high-temperature gasification process and melting of electronic components and computer equipment using plasma reactor technology. It analyses the marginal conditions of batch processing, as well as the formation of solid products which result from the procedure of waste processing. Attention is also paid to the impact of the emerging products on the environment.
\end{abstract}

Key words: plasma technology, electronic waste, alloy, glassy slag, syngas

\section{Introduction}

The introduction of the information and communication technology into everyday life in the second half of the twentieth century and the digitization of manufacturing processes instigated mass production and caused a high demand for electrical and electronic appliances. Generated waste, in the form of discarded equipment with a number of circuit boards, leaded glass, etc., became hazardous waste requiring special treatment. At present, due to the rapid technological evolution, computers, control and communication devices have shorter life span than in the past. For that reason, the amount of electrical and electronic waste increases every year [1].

Recycling, reuse and recovery of discarded or dysfunctional equipment represents secondary sources of metals that can be used in the manufacture of the same or similar products, thus avoiding landfilling.

In order to protect the environment and the natural resources, a set of strict quotas for the recycling of electrical and electronic equipment was implemented within the European Union. In accordance with the requirements of the European Parliament and the Council Directive 2002/96/EC of 27 January 2003 on waste from the electrical and electronic equipment, the following objectives have been set:

Collect annually at least $4 \mathrm{~kg} / \mathrm{habitant}$ of WEEE from private households. 
Ensurean annual rate of recovery and recycling according to information provided in the corresponding Table 1 .

Table 1: The recovery, reuse and recycling of components, materials and substances in electrical and electronic equipment

\begin{tabular}{|c|c|c|}
\hline Category of e-waste & $\begin{array}{c}\text { Rate of reuse (\%) } \\
\text { (from the average } \\
\text { weight of the } \\
\text { component) }\end{array}$ & $\begin{array}{c}\text { Rate of the reuse and } \\
\text { recycle of components, } \\
\text { materials and fabrics (\%) } \\
\text { (from the average weight of } \\
\text { the component) }\end{array}$ \\
\hline Large household appliances & 80 & 75 \\
\hline Small household appliances & 70 & 50 \\
\hline $\begin{array}{c}\text { Information } \\
\text { \& telecommunication } \\
\text { components }\end{array}$ & 75 & 65 \\
\hline $\begin{array}{c}\text { Consumer electronic } \\
\text { Electric and electronic } \\
\text { machines } \\
\text { (except large stationary industry } \\
\text { machines) }\end{array}$ & 75 & 65 \\
\hline $\begin{array}{c}\text { Machines for monitoring and } \\
\text { control }\end{array}$ & 70 & 50 \\
\hline
\end{tabular}

The limit indicators listed in Table 1 are difficult to fulfil only by recycling the metal and ceramic portion of electrical and electronic waste [2]. Questions are arising regarding the targeted solution to the recovery of plastic portion of waste, as it represents about $20-30 \%$ of the waste content and it continues to grow [3]. Mechanical recycling of plastic fragments and its reintroduction into production processes is, in many cases, an inefficient approach from economic and qualitative terms. The combustion of plastics, as the most widely used thermal process of disposal of organic waste material, delivers a range of difficulties to deal with that are mainly connected to the environmental contamination by toxic and dangerous products. Cell phones and other electronic components, despite their small size, have a high potential for contamination because in each device there are 5-12 items, such as mercury $(\mathrm{Hg})$, cadmium $(\mathrm{Cd})$, lead $(\mathrm{Pb})$, arsenic (As), dioxins and furans arising from the combustion, which are considered to be very harmful to health and the environment. These substances can pollute the air, soil or water. Many of these pollutants can persist in the environment through bioaccumulation via the food chain. This means that electronic waste is often categorized as hazardous waste that requires special handling. Hence, the appropriate ways of disposal are being explored, not only in terms of the metal recycling, but mainly in terms of the need to protect the environment [4].

Plasma technology, that is a proven technology in the processing of waste containing a significant share of metal components produced in the metallurgy industry, appears to be a promising technology in the treatment of WEEE. 


\section{Material and Technology}

An experimental test sample is obtained from a dismantled computer unit. Simple on its face, the electronic components represent heterogeneous waste containing different types of metals, plastics, glass and ceramics. To identify the material content of such a batch, a pre-treatment is therefore required, preceding the high temperature treatment process. In the first step of preparation, the sample is crushed to a fraction of less than $5 \mathrm{~mm}$. The moisture content in the sample was set to $0.72 \mathrm{wt}$. \%. The rate of the organic compounds and plastics in the sample of electronic waste was determined by oxidative annealing at $850{ }^{\circ} \mathrm{C}$. The annealed sample is then digested in aqua regia. By analyzing the leachate and the undissolved residue, a recovery factor of various elements and compounds was detected. Summary of an average composition of a crushed and homogenized sample of electronic waste provides Table 2 [2].

Table 2: Average composition of crushed samples of electronic waste

\begin{tabular}{|c|c|}
\hline Compound & $\begin{array}{l}\text { Average } \\
\text { composition } \\
\text { (w. \%) }\end{array}$ \\
\hline \multicolumn{2}{|l|}{ Annealing losses at $850{ }^{\circ} \mathrm{C}$} \\
\hline Organic part + plastics & 56.04 \\
\hline $\begin{array}{l}\text { Amount of elements in the } \\
\text { extract obtained from the } \\
\text { leaching of the residue after } \\
\text { the oxidation annealing }\end{array}$ & 32.11 \\
\hline $\mathrm{Cu}$ & 57.76 \\
\hline $\mathrm{Al}$ & 19.23 \\
\hline $\mathrm{Fe}$ & 2.89 \\
\hline $\mathrm{Ca}$ & 6.55 \\
\hline $\mathrm{Mg}$ & 0.31 \\
\hline $\mathrm{Mn}$ & 0.055 \\
\hline $\mathrm{Ag}$ & 0.101 \\
\hline $\mathrm{Au}$ & $1.74 \mathrm{mg} \cdot \mathrm{kg}^{-1}$ \\
\hline $\mathrm{B}$ & 0.53 \\
\hline $\mathrm{Cd}$ & 0.0023 \\
\hline $\mathrm{Cr}$ & 0.005 \\
\hline $\mathrm{Ni}$ & 0.246 \\
\hline $\mathrm{Pb}$ & 2.23 \\
\hline $\mathrm{Sn}$ & 1.11 \\
\hline $\mathrm{V}$ & 0.005 \\
\hline $\mathrm{Zn}$ & 5.12 \\
\hline $\mathrm{SiO}_{2}$ & $<0.03$ \\
\hline $\begin{array}{l}\text { Amount of elements in the } \\
\text { undissolved residue } \\
\text { obtained from the leaching } \\
\text { of the residue after the } \\
\text { oxidation annealing }\end{array}$ & 11.85 \\
\hline $\mathrm{SiO}_{2}$ & 54.25 \\
\hline
\end{tabular}




\begin{tabular}{|c|r|}
\hline $\mathrm{Al}_{2} \mathrm{O}_{3}$ & 8.37 \\
\hline $\mathrm{Fe}_{2} \mathrm{O}_{3}$ & 6.40 \\
\hline $\mathrm{CaO}$ & 4.96 \\
\hline $\mathrm{MgO}$ & 0.57 \\
\hline $\mathrm{MnO}$ & 0.023 \\
\hline $\mathrm{TiO}_{2}$ & 0.76 \\
\hline $\mathrm{Sn}$ & 8.84 \\
\hline $\mathrm{Cr}$ & 0.13 \\
\hline $\mathrm{Cu}$ & 0.52 \\
\hline $\mathbf{S u m}$ & $\mathbf{1 0 0 . 0 0}$ \\
\hline
\end{tabular}

Based on the results shown in Table 2 it can be concluded that the metal content in the recyclable waste is at the level of about $30 \%$ of the total weight of the electronic waste. Such proportional representation of metals in e-waste is not, in terms of its reuse, negligible and its recovery thought plasma melting processes will depend on the course of chemical reactions taking place in the reaction chamber of the plasma reactor. The quantity of emerging products in the form of an alloy, oxide particulates or slag will affect mainly the operating conditions characterizing the process of melting.

The melting temperature of the emerging slag will depend on the content of the main slagforming oxide in the charge. Furthermore, the temperature will be influenced by the process of oxidation of aluminium into aluminium oxide found in the sample of electronic waste. Considering the percentage of main slag-forming oxides in the batch and the oxidation of approximately $50 \%$ aluminium into aluminium oxide, the melting temperature of the emerging oxidizing melting substance should be reduced by adding a fluxing agent. Due to the high content of acidic slag-forming components and plastics in electronic waste, a dolomitic limestone as a flux is used, containing $55 \mathrm{wt} . \%$ of $\mathrm{CaCO}_{3}, 30 \mathrm{wt} . \%$ of $\mathrm{MgCO}_{3}$ and 5 wt. $\%$ of $\mathrm{SiO}_{2}$, respectively [2].

High temperature processing of crushed samples of e-waste, with the objective of the material and the energy recovery of the content, took place in a plasma reactor operated in a dependent connection. To generate the low-nitrogen plasma, a nitrogen gas was used. The graphite hearth was protected against wear by creating a highly conductive copper layer on the bottom of the reactor. The total weight of the embedded copper lining is $5.7 \mathrm{~kg}$. More detailed specifications of the technology are shown in lit. 4-7.

\section{Experimental melting samples of electronic waste}

The high temperature processing of e-waste, originating from the discarded computer equipment, was carried out at an average temperature of $1410{ }^{\circ} \mathrm{C}$ in a laboratory plasma reactor with a dependent arc. The inserted batch with a weight of $16.7 \mathrm{~kg}$ consisted of 71.43 wt. $\%$ of electronic waste and $28.57 \mathrm{wt} . \%$ of dolomitic limestone. The increase of a flux in a form of dolomitic lime provides an additional benefit in a form of the oxygen potential increase in the reaction chamber of the plasma reactor. This is an added advantage to the reduction of the melting temperature of the emerging oxide melting substance. During the thermal decomposition, the substances of $\mathrm{CaCO}_{3}$ as well $\mathrm{MgCO}_{3}$ release the $\mathrm{CO}_{2}(1,2)$ 


$$
\begin{aligned}
& \mathrm{CaCO}_{3_{(\mathrm{s})}}=\mathrm{MgO}_{(\mathrm{s})}+\mathrm{CO}_{2(\mathrm{~g})} \\
& \mathrm{MgCO}_{3(\mathrm{~s})}=\mathrm{MgO}_{3(\mathrm{~s})}+\mathrm{CO}_{2(\mathrm{~g})}
\end{aligned}
$$

Untreated carbon in the presence of carbon dioxide oxidizes partially into oxide monoxide, thereby increasing the recovery of the carbon forming part of the plastic charge. The oxidation of carbon in the presence of carbon dioxide into carbon monoxide contributes to a greater use of the energy potential of plastics present in electronic waste [2].

Time required to conduct the laboratory experiment was 73 minutes at the marginal conditions at the speed of the batch insertion of $0.229 \mathrm{~kg} \cdot \mathrm{min}^{-1}$. Total energy consumption per $\mathrm{kg}$ of the treatment mixture of electronic waste and flux (limestone dolomite) was around $3 \mathrm{kWh} \cdot \mathrm{kg}^{-1}$.

Four outputs of the high-temperature melting process and gasification of electronic waste in the plasma reactor are: oxide-melting substance in a form of slag, metal alloy, synthesis gas and flue dust. The composition of solid products can be seen in Table 3, 4, 5. The average composition of the synthesis gas generated at a volume of $0.498 \mathrm{~m}^{3} \mathrm{~kg}^{-1}$ of the batch corresponds to the following values: $0.15 \mathrm{CH}_{4} ; 47.50 \mathrm{H}_{2} ; 0.28 \mathrm{O}_{2} ; \mathrm{N}_{2} 15.70 ; 0.43 \mathrm{CO}_{2} ; \mathrm{CO}$ $36.00 ; 0004 \mathrm{C}_{2} \mathrm{H}_{4} ; \leq 0.001 \mathrm{C}_{2} \mathrm{H}_{6} ; 0008 \mathrm{C}_{2} \mathrm{H}_{2} ; 0003$ amount $\mathrm{C} 3-8$ hydrocarbons [2].

\begin{tabular}{|c|c|}
\hline Compound & $\begin{array}{c}\text { Composition } \\
\text { (w. \%) }\end{array}$ \\
\hline $\mathrm{Cu}$ & 80.5 \\
\hline $\mathrm{Al}$ & 7.21 \\
\hline $\mathrm{Si}$ & 4.89 \\
\hline $\mathrm{Sn}$ & 3.91 \\
\hline $\mathrm{Fe}$ & 2.44 \\
\hline $\mathrm{Ni}$ & 0.316 \\
\hline $\mathrm{Cr}$ & 0.157 \\
\hline $\mathrm{Ag}$ & 0.0563 \\
\hline $\mathrm{Au}$ & 0.0163 \\
\hline $\mathrm{S}$ & 0.0095 \\
\hline $\mathrm{Cd}$ & 0.00046 \\
\hline $\mathrm{Te}$ & $>0.144$ \\
\hline $\mathrm{C}$ & $>0.0732$ \\
\hline $\mathrm{Zn}$ & $<0.003$ \\
\hline $\mathrm{Pb}$ & $<0.05$ \\
\hline $\mathrm{Sb}$ & $<0.0035$ \\
\hline $\mathrm{Co}$ & $<0.0015$ \\
\hline $\mathrm{Be}$ & $<0.0001$ \\
\hline $\mathrm{B}$ & $<0.0004$ \\
\hline $\mathrm{Pt}$ & $<0.002$ \\
\hline
\end{tabular}

Table 3: Composition of the metal alloy 
Table 4: Composition of the slag

\begin{tabular}{|c|c|}
\hline Compound & $\begin{array}{c}\text { Composition } \\
\text { (w. \%) }\end{array}$ \\
\hline $\mathrm{CaO}$ & 46.71 \\
\hline $\mathrm{Al}_{2} \mathrm{O}_{3}$ & 31.16 \\
\hline $\mathrm{SiO}_{2}$ & 3.27 \\
\hline $\mathrm{MgO}$ & 0.12 \\
\hline $\mathrm{Cu}$ & 13.03 \\
\hline $\mathrm{Fe}$ total & 0.55 \\
\hline $\mathrm{Sn}$ & 0.132 \\
\hline $\mathrm{Zn}$ & 0.071 \\
\hline $\mathrm{Pb}$ & 0.028 \\
\hline $\mathrm{Ag}$ & 0.0046 \\
\hline $\mathrm{Sum}$ & $\mathbf{8 0 . 6 2}$ \\
\hline
\end{tabular}

Table 5: Composition of the fly ash

\begin{tabular}{|c|c|}
\hline Compound & $\begin{array}{c}\text { Composition } \\
\text { (w. \%) }\end{array}$ \\
\hline $\mathrm{C}$ & 40.02 \\
\hline $\mathrm{CaO}$ & 16.04 \\
\hline $\mathrm{MgO}$ & 10.35 \\
\hline $\mathrm{SiO}_{2}$ & 5.60 \\
\hline $\mathrm{Cu}$ & 6.13 \\
\hline $\mathrm{Pb}$ & 3.90 \\
\hline $\mathrm{Zn}$ & 1.45 \\
\hline $\mathrm{Fe} \mathrm{total}$ & 0.19 \\
\hline $\mathrm{Cd}$ & 0.01 \\
\hline Sum & $\mathbf{8 3 . 6 9}$ \\
\hline Humidity & 3.55 \\
\hline
\end{tabular}

\section{Results and Discussion}

Stability of metal oxides in the mixture, similarly as in lit. [2, 6] can be measured by observing changes in standard Gibbs free energy [8]. Stable slag-forming oxides, such as in particular $\mathrm{SiO}_{2}, \mathrm{Al}_{2} \mathrm{O}_{3}, \mathrm{CaO}, \mathrm{MgO}$ and $\mathrm{TiO}_{2}$, will concentrate at the bottom of the reactor in the form of a slag. Less stable oxides like $\mathrm{Cu}_{2} \mathrm{O}, \mathrm{Fe}_{2} \mathrm{O}_{3}, \mathrm{NiO}, \mathrm{SnO}_{2}, \mathrm{CdO}, \mathrm{ZnO}$, and $\mathrm{PbO}$ are, under given conditions, directly or indirectly reduced in metal $(\mathrm{Cu}, \mathrm{Fe}, \mathrm{Ni}, \mathrm{Sn}, \mathrm{Cd}, \mathrm{Zn}$ and $\mathrm{Pb})$, following the chemical reactions $(3,4)$.

$$
\begin{gathered}
\mathrm{MeO}_{(\mathrm{l})}+\mathrm{C}_{(\mathrm{s})} \rightleftharpoons \mathrm{Me}_{(\mathrm{l} ; \mathrm{g})}+\mathrm{CO}_{(\mathrm{g})} \\
\mathrm{MeO}_{(\mathrm{l})}+\mathrm{CO}_{(\mathrm{g})} \rightleftharpoons \mathrm{Me}_{(\mathrm{l} ; \mathrm{g})}+\mathrm{CO}_{(\mathrm{g})}
\end{gathered}
$$

Wherein: MeO represents oxides of the less stable metal oxides 
Me - the reduced metal,

(L) - liquid phase (liquidus),

(G) -gaseous phase (gaseus),

$(\mathrm{L} ; \mathrm{g})$ - liquid and gaseous phase,

(S) - solid phase (solidus) [2].

Metals with a high boiling point and with a low pressure of metal vapors (e.g. $\mathrm{Fe}, \mathrm{Cu}, \mathrm{Sn}$, and $\mathrm{Ni}$ ), found in less stable oxides, are, as a separate phase, concentrated at the bottom of the plasma reactor. $\mathrm{Hg}, \mathrm{Cd}, \mathrm{Zn}$ and $\mathrm{Pb}$ are concentrated in the synthesis gas and reduced to fly ash in cleaning facilities.

Slag-forming oxides are concentrated in the oxide layer situated above the molten metal alloy. By tapping the melt, a slag with an amorphous glassy silicate structure is obtained. Unlike the batch that enters the process of high temperature gasification and smelting, the slag has an inert character with a very low leachability of metals. The composition of glassy slag can also be modified with the application of other types of fluxes, which creates conditions for its future use, for example construction.

Throughout the process of plasma melting and gasification of electronic waste (when considering the results of the composition analysis of metal alloy - Table 3), the partial or complete reduction of $\mathrm{SiO}_{2}$, found in the charge, occurred. As a result of the high temperature and different chemical reactions taking place in the reaction chamber, the silica is partially reduced in metal $\mathrm{Si}$ concentrated in alloy, (Table 3). Process of reduction of $\mathrm{SiO}_{2}$ into volatile $\mathrm{SiO}$ and into metal $\mathrm{Si}$ is also confirmed by the analysis of the slag (Table 4).Some of the oxides, originated in e-waste, are reduced in a strong reduction atmosphere. Metals with a high boiling point $(\mathrm{Cu}, \mathrm{Ni}, \mathrm{Fe}$, etc.) are concentrated at the bottom of the reactor, where they may be periodically tapped.

The high content of copper in the alloy affects the metal copper, which was placed into the reaction chamber of the plasma reactor before the start of the experiment in order to protect the graphite heart. Based on the experience, approximately 50\% of copper evaporates during the pre-heating period of the reactor and condenses in the cooler areas of technological units. This problem is eliminated by continuous operation, during which the reduced metal is protected by the oxide melt [2].

Deficit in the oxygen potential in the reaction chamber of the plasma reactor can be determined based on the percentage level of carbon in the fly ash [9-11]. The concentration of carbon in the metal alloy and in the slag is negligible. When assuming that there is about 50$60 \%$ of carbon in the organic fraction of electronic waste, the hypothetical production of syngas is around 1.020 to $1.225 \mathrm{~m}^{3} \cdot \mathrm{kg}^{-1}$; however, only if $100 \%$ of the carbon potential found in waste is used (carbon balance in the composition corresponding to the average composition of the syngas). Based on the above, the efficiency of the use of the mass fraction of carbon at the formation of gaseous components is less than $50 \%$. Increase in the production of synthesis gas is possible by further increase of the oxygen potential in the reaction chamber of the plasma reactor and by further regulation the marginal conditions of the process of high temperature gasification and melting of electronic waste. The energy of such synthesis gas can be re-used after the gas is cleaned, ex. in cogeneration units for the production of electricity and heat. 


\section{Conclusion}

In many cases, obsolete and discarded computers for individual use and electrical and electronic equipment in general, still have an added social value. Re-use of otherwise functional devices on the secondary market without modification, either by selling for a nominal fee or donation, reduces the volume of the emerging e-waste and conserves natural resources.

One of a few possible and presently only marginally regarded options for the recovery of e-waste is the high-temperature melting technology in the plasma reactor. As confirmed by this experiment, the applied technology provides not only material but also partial energy recovery of waste. Produced synthesis gas may be used for energy purposes after being cleaned. An additional advantage of the technology is the possibility to recover the metal portion of waste that, if landfilled, would become irreversibly lost as a degraded raw material.

Based on the analysis of products formed in the process of melting and gasification of e-waste, the technology is considered technically and ecologically suitable. If the marginal conditions for the process are correctly set, we consider this technology as BAT technology; one where the material and energy content of the batch is recovered.

\section{Acknowledgements}

The article was created with the support of the Ministry of Education for the EU Structural Funds Operational Program "Research and Development" project no. p. ITMS 26220220044 Project and KEGA 003TUKE-4/2016.

\section{References}

[1] Scharnhorst, W., et. al. (2007). Heavy metal partitioning from electronic scrap during thermal End-of-Life treatment. Science of the Total Environment. Volume (373), p. 576-584.

[2] Lázár, M., et. al. (2015) Pyrometalurgické spracovanie elektronického odpadu plazmovou technológiou. Chemické listy. Volume (109), p. 543-549)

[3] Stenvall, E., et. al. (2013). An analysis of the composition and metal contamination of plastics from waste electrical and electronic equipment. Waste Management. Volume (33), p. 915-922.

[4] Čarnogurská, M., Lázár, M. (2013). Plazmové spracovanie a zhodnocovanie odpadu. Košice: TU.

[5] Lázár, M., et. al. (2015). High-temperature gasification of RDF waste and melting of fly ash obtained from the incineration of municipal waste. Acta Polytechnica. Volume (55), n. 1, p. 1-6.

[6] Čarnogurská, M., et. al. (2015). Measurement and evaluation of properties of MSW fly ash treated by plasma. Measurement. Volume (62), p. 155-161.

[7] Imriš, I., Klenovčanová, A. (2009). The plasma gasification and smelting unit. Acta Mechanica Slovaca. Volume (13), n. 2, p. 6-11.

[8] Komorová, L., Imriš, I. (1992). Termodynamika v hutníctve. Bratislava: Alfa.

[9] Jílek, J. (1953). Moderní způsoby zplynování paliv kyslíkem. Praha: Státní nakladatelství technické literatury. 
[10] Lukáč, L., Kuna, Š.,Kizek, J., Repášová, M. (2013). Design of methodology for wood chips moisture estimation determined for gasification. Experimental fluid Mechanics. 2013, p. 429432.

[11] Kočanová, S., Lukáč, L., Széplaky, D., Lazić, L. (2014). The impact of contaminated biomass for the formation of emission in the combustion process of producer gas in the cogeneration. The application of experimental and numerical methods in fluid mechanics and energetic. 2014, p. 123-127. 
